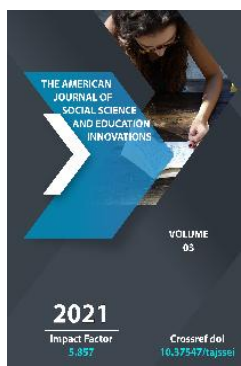

\title{
Occasional Use Of Another`s Work
}

\author{
Alimov Nodir Yunusovich \\ National Institute Of Fine Arts And Design, Uzbekistan
}

Journal Website:

http://theamericanjour

nals.com/index.php/taj

ssei

Copyright: Original content from this work may be used under the terms of the creative commons attributes 4.0 licence.

\section{ABSTRACT}

The randomness should not be deliberately created in the stituation of random utilize of another's work. Providing that this occasion not intentionally created, an individual who accidentally used someone else's work of authorship is exempt from liability.

\section{KEYWORDS}

The right of authorship, photographic works, catalog, free use, random use, composition, basic object.

\section{INTRODUCTION}

It is well-known fact that, the Republic of Uzbekistan has commenced to carry out suitable process to protect the rights of authors, owners of intellectual property rights, and the averting of copyright infringement has become one of the most 
pressing issues at present. On October 12, 2020, the President of the Republic of Uzbekistan Mirziyoyev Shavkat Miromonovich stated "the pivotal and diversity steps for the amelioration of the industry, the improvement of legislation in this area, the significant introduction of intellectual property in the process of training, increasing the legal culture and respect for intellectual property in community" on October 12,2020. Government officials entrusted the Intellectual Property Agency under the Ministry of Justice of the Republic of Uzbekistan with major and crucial tasks in implementing these measures. The main purpose of the Intellectual Property Agency is not to severely punish an authorship infringer, but to hamper such violations, to explain the consequences and, most importantly, to build respect for the author in every condition whatever the situation is.

Furthermore, it is crucial to emphasize that the students are taught with "Copyright" in the field of intellectual property in the bachelor's degree and "Patent Studies" in the master's degree at National Institute of Art and Design named after Kamoliddin Behzod of the Academy of Arts of the Republic of Uzbekistan. Students who study at this Institute should realize the limits, order, random use of another's work in the process of developing author's works.

It is irrefutable notion that one of the old and prominent questions of copyright is to define in what cases a work of another person may be utilized without the permission of the right holder in the creation of his original and super work, except for the limits of use and types of free use.
First and foremost, If we imagine a photographer creates a series of original photographic works with the help of his attempts and knowledge, and the photographs describe models wearing jewelry that belongs to third parties. The copyright to these photographs belongs to the photographer, notwithstanding, as far as the legality of the use of the jewelry is concerned among majority of human beings, has this permission been taken from the owner of the jewelry or not?

There is no doubt that in the process of creating the composition, the photographer decided to turn to the model jewelry encompassing rings, necklaces and earrings; jewelry is selected in harmony with the help of the model's eyes, body colors, and their clothes.

Can an owner of jewelry rights can prohibit the use of photographs that are being created at the moment? Articles 26-32 of the Law of the Republic of Uzbekistan called "On Copyright and Related Rights" determine the various types of free use of works, which cannot maintain in this case.

The photographer might have utilized someone else's jewelry in his work, we should make it clear that would it be a violation of the law or not?

I am going to present two suitable and basic examples related to this. The first example here is that a photographer is on the eve of creating a catalog, while walking down the street, he deliberately discerned a girl and asked her to take a picture, the girl was wearing jewelry, in the second example, the 
photographer presented and photographed the jewelry to a girl he knew at that time.

We cannot neglect the fact that according to our current national law, the photographer is detected to have infringed the copyright of another in both of the above-mentioned examples.

Everyone knows that the decision of the German Supreme Civil Court indicates a new and modern view on copyright protection. We should also emphasize that this decision adopted by German does not comply with the decisions of the Court of Justice of the European Union, which specializes in the protection of copyright (the limitations and exceptions provided for in Article 5 of the Copyright Directive 2001/29).

In addition to this, case ZR $177 / 13$ of 17 November 2014 is a case in our point of which should not be neglected. The respondent (furniture manufacturer) published a catalog of furniture and definitely posted an electronic version of the catalog on its website. The catalog includes a photo of the defendant's product - the inner component of the room, in which the work of fine art hanging on one of the walls of the room belongs to the plaintiff (artist), as well as the plaintiff filed a lawsuit alleging copyright infringement.

Initially, the courts of first instance and appellate instance refused the claim. It is irrefutable that, the denial is based on Article 57 of the German Copyright Act, which claims that the plaintiff's work was deliberately dropped into the furniture interior catalog. This Article specializes in the protection of copyright who is in line with the decisions of the European Court of Justice, (the limitations and exceptions provided for in Article 5 of the Copyright Directive 2001/29): we should also state that the exception does not demand the consent of the right holder.

Moreover, the court's evaluation of the criterion of "randomness" is mostly based on the degree to which the average spectator understands the criterion of "randomness" in the use of another's work in this situation.

Multitude of individuals deem that the first criterion for evaluation is the "main object" called the catalog of furniture. It encompasses a number of images, in this situation the image of the plaintiff's work of fine art is deemed the main object. The real data that the entire catalog is not considered a "primary object" contradicts the application of the exceptions and limitations provided for in Article 5 of the Copyright Directive 2001/29.

The second criterion for evaluation called "randomness". It was the use of someone else's work by accident based on the composition of the main object? The fact that the artist's work of fine art is not in the main background in the image of furniture accessories does not matter in content, the "randomness" must be clear and exact.

The German Supreme Civil Court utilized a two-stage test:

A) The first one is interchangeability: it is deemed as random if the artist's work of fine art can be easily took place by the work of another artist, or it does not impact the image of furniture if no work is replaced in the same place at all;

B) The next stage is not to be a part of the composition: if an objective, mediocre spectator perceives the artist's work of 
fine art as an important part of the composition, it means that someone else's work was deliberately utilized. If we perceived it as a crucial part of the composition, we did not utilize it deliberately.

We should realize that court upheld the claim because the plaintiff's (right holder) work had a certain aesthetic value in the composition of the photographic work depicting the interior of the furniture. It was this work of fine art that was selected and considered not to have emerged by accident when it was created.

It is a usual situation that there are gaps and issues in the national legislation of each state. When there are gaps in the law, we should regulate this or that relationship, should be definitely resolved under the current principle of justice. There is no doubt that the elimination of these gaps will be the focus of lawmakers.

It is definite that as a result of comparison of our of the European Union, in particular, Germany, it is proposed that Article 61 of the Law of the Republic of Uzbekistan "On Copyright and Related Rights" be as follows:

"Article 61. Liability for Violation of Copyright and Related Rights Legislation:

Human being guilty of violating the legislation shall be liable in the prescribed and given manner on copyright and related rights.

If the accident was not intentionally created, a person who deliberately utilizes someone else's work shall be exempt from liability"
1.

2.

http://www.legalshift.com.ua/?p=326

https://www.facebook.com/search/to p?q=Интеллектуал\%2оМулк\%2оАгентл иги\%2оМатбуоти

3. Сайфуллаев Н. ЮРТИМИЗ БАДИИЙ ТАЪЛИМ СОХАСИНИНГ ЭРТАНГИ РИВОЖИ УЧУН ЯНА БИР МУХИМ АСОС ЯРАТИЛДИ //Камолиддин Бехзод номидаги Миллий рассомлик ва дизайн институти АХБОРОТНОМАСИ илмий-амалий журнали. - 2021. - Т. 5. - №. 01

4. Utanova U. A. et al. ScientificallyPhilosophical Analysis Of Cultural And Spiritual Heritage //International Journal on Integrated Education. 2019. - T. 2. - №. 1. - C. 53-55.

5. Утанова У. А. Общечеловеческое и национальное в народной культуре //Сборники конференций НИЦ Социосфера. - Vedecko vydavatelske centrum Sociosfera-CZ sro, 2014. - №. 38. - C. 91-95.

6. Utanova U. A. FOLK CULTURE IS A SOCIO-HISTORICAL PHENOMENON //International Engineering Journal For Research \& Development. - 2020. - T. 5. - №. 9. - C. 5-5.

7. Утанова У. «НАРОДНАЯ КУЛЬТУРА»: ПОНЯТИЕ, СУЩНОСТЬ, СОЦИАЛЬНОФИЛОСОФСКИЙ АНАЛИЗ

//Современные научные исследования: актуальные теории и концепции. - 2016. - С. 183-185.

8. Utanova U. A. et al. ScientificallyPhilosophical Analysis Of Cultural And Spiritual Heritage //International Journal on Integrated Education. 2019. - T. 2. - №. 1. - C. 53-55.

9. Fayazova F. Methodology of Vocational Training And Pedagogical Practice As The Main Factors In The

\section{REFERENCES}


Preparation Of A Future Teacher Of Vocational Training//The American Journal of Social Science and Education Innovations. - 2021. - T. 3. №. 03. - C. 27-31.

10. Makhmudova M., Jumaniyazova D., Abdullahodjaev G. The Landscape Design of the Art Nouveau Style /ISOCIETY. INTEGRATION. EDUCATION. Proceedings of the International Scientific Conference. 2015. - T. 2. - C. 391-400.

11. Abdullakhodjaev G. T. Protection Of Moral And Material Rights of Copyright Subjects //The American Journal of Social Science and Education Innovations. - 2021. - T. 3. №. 03. - C. 73-80.

12. Рашидов Ж. Х. У. СпОСОБЫ ИНТЕРПРЕТАЦИИ

ХУДОЖЕСТВЕННОЙ ЛИТЕРАТУРЫ В КНИЖНОЙ ГРАФИКЕ //ПроблеМЫ современной науки и образования. 2020. - №. 2 (147).

13. Рашидов ж. Х. У. Книжные иллюстрации как средство эстетического формирования дошкольников //Проблемы современной науки и образования. 2020. - №. 1 (146).

14. Рашидов Ж. Х. У. СОВРЕMЕНHЫЕ ПРОБЛЕМЫ И ТЕНДЕНЦИИ РАЗВИТИЯ КНИЖНОГО ДИЗАЙНА //Вестник науки и образования. 2020. - №. 24-1 (102).

15. Алимов H. Ю. COPYRIGHT PROTECTION THROUGH BLOCKCHAIN //Актуальные научные исследования в современном мире. - 2019. - №. 56. - С. 26-28.

16. Маруфбаев Б. Ш. ЭТНОКУЛЬТУРНОЕ МЫШЛЕНИЕ-КРИТЕРИЙ
НАЦИОНАЛЬНО-ДУХОВНОГО

РАЗВИТИЯ //Актуальные научные исследования в современном мире. - 2018. - №. 2-4. - C. 60-64.

17. Sherbekovich M. B. Contemporary Art Is A Factor For Developing Democratic Thinking, Forming A Strong Citizen Position //The American Journal of Social Science and Education Innovations. - 2020. - T. 2. - №. 11. - C. 557-561.

18. Djumaniyazova D. Humanity And Divinity Are The Objects Of Sufi Teachings //The American Journal of Social Science and Education Innovations. - 2021. - T. 3. - №. 03. - C. 16-26.

19. Dilfuza D. HUMANITY AND DIVINITY RESEARCHES IN THE ORIENTAL PHILOSOPHY //Theoretical \& Applied Science. - 2017. - №. 10. - C. 51-53.

20. Kamalovna J. D. Humanity And Divinity In The Interpretation Of Eastern Philosophy //The American Journal of Social Science and Education Innovations. - 2020. - T. 2. - №. 11. - C. 552-556.

21. Makhmudova M., Jumaniyazova D., Abdullahodjaev G. The Landscape Design of the Art Nouveau Style I/SOCIETY. INTEGRATION. EDUCATION. Proceedings of the International Scientific Conference. 2015. - T. 2. - C. 391-400.

22. Холдарова Ф. СИЁСИЙ МУЗОКАРАЛАР МУВАФФАҚИЯТИНИ ТАЪМИНЛАШДАГИ АХБОРОТ ТЕХНОЛГИЯЛАРНИНГ АХАМИЯТИ //Камолиддин Бехзод номидаги Миллий рассомлик ва дизайн институти АХБОРОТНОМАСИ илмий- 
амалий журнали. - 2021. - Т. 5. - №.

01.

23. Хасанов Р. ЎРТА АСРЛАР ШАРҚ ОЛАМИ МАЪНАВИЙ ВА МАЪРИФИЙ ФИКР ТАРАҚҚИЁТИДА АЛИШЕР НАВОИЙНИНГ ТУТГАН ЎРНИ //Камолиддин Бехзод номидаги Миллий рассомлик ва дизайн институти АХБОРОТНОМАСИ илмийамалий журнали. - 2021. - Т. 5. - №. 01.

24. Машарипова Г. ЁшЛАРДА ғОяВИЙ ИММУНИТЕТНИ

РИВОЖЛАНТИРИШДА МАЪНАВИЙ ОМИЛЛАРНИНГ ЎРНИ //Камолиддин Бехзод номидаги Миллий рассомлик ва дизайн институти АХБОРОТНОМАСИ илмий-амалий журнали. - 2021. - Т. 5. - №. 01.

25. Каланов А. БАДИИЙ АДАБИЁТНИНГ ТАЪСИРЧАНЛИГИДА РАССОМНИНГ ЎРНИ //Камолиддин Бехзод номидаги Миллий рассомлик ва дизайн институти АХБОРОТНОМАСИ илмий-амалий журнали. - 2021. - Т. 5. - №. 01.

26. Kurbanova, D. A. (2016). ANCIENT PEARLS IN GREAT WORLD MUSEUMS WHICH BELONG TO THE HISTORY OF UZBEKISTAN AND LEARNING THEM. Социосфера, (3), 55-61. 